\title{
ISOLATION OF Arcobacter spp FROM POULTRY CARCASSES, IN BRAZIL
}

\author{
ISOLAMENTO DE Arcobacter spp DE CARCAÇAS DE FRANGO NO BRASIL
}

\author{
Sérgio José de Oliveira ${ }^{1-2}$ Hamilton Luiz de Souza Moraes ${ }^{2-3}$ Beatris Sonntag Kuchenbecker $^{2}$ \\ Nilo Ikuta ${ }^{4-5}$ Vagner Lunge $^{4-5}$ André Fonseca $^{5}$ José Rafael Coiro $^{6}$
}

\section{SUMMARY}

Fourty eight isolates of Arcobacter spp were obtained from 37 poultry carcasses, from abattoir, among 80 carcasses examined. Attempts for culturing were made from the skin and muscle, resulting on 25 positive cultures from muscle and 23 from skin. Classification was achieved by phenotypic characterization and $P C R$ and multiplex $P C R$, resulting 41 samples of Arcobacter butzleri and 07 Arcobacter sp. This is the first report on the occurrence of Arcobacter in animal carcasses in Brazil.

Key words: Arcobacter sp, Arcobacter butzleri, poultry carcasses.

RESUMO

Foram isoladas 48 amostras de Arcobacter spp de 37 carcaças de frangos colhidas em frigorífico, prontas para consumo, entre 80 carcaças examinadas. Foram feitas tentativas de cultivo a partir de pele e de músculo, sendo obtidas 25 cultivos positivos de músculo e 23 de pele. As bactérias foram classificadas pelas características fenotípicas e pelo teste de PCR e PCR múltiplo, obtendo-se 41 amostras classificadas como Arcobacter butzleri e 07 com classificação a nível de gênero Arcobacter sp. Estes são os primeiros relatos sobre a ocorrência das bactérias em carcaças de animais no Brasil.

Palavras-chave: Arcobacter sp, Arcobacter butzleri, carcaças de frango.

\section{INTRODUCTION}

The genus Arcobacter includes bacteria that were formerly designated "aerotolerant
Campylobacter" because they grew in the presence of atmospheric oxygen. It was suggested the designation of Campylobacter cryaerophila (NEILL et al., 1985) and inclusion in the genus Campylobacter.

In view of phenotypic and genotypic differences from Campylobacter spp, the genus Arcobacter was proposed for the organisms (VANDAMME et $\boldsymbol{a l}$., 1991). The species of Arcobacter associated with human and animal disease are A. cryaerophilus (DNA groups 1A and 1B), A. butzleri and A. skirrowii.

A. cryaerophilus has been isolated from aborted porcine fetuses, sows with reproductive problems and preputial fluid of male pigs (ELLIS $\boldsymbol{e} t$ al.,1978; NEILL et al.,1979; SCHROEDERTUCKER et al., 1996). A. butzleri has been cultured from human cases of enteritis (TAYLOR et al., 1991; KIEHLBAUCH et al., 1991; PUGINA et al., 1991; LERNER et al., 1994; LAUWERS et al., 1996), drinking water reservoirs (JACOB et al., 1993), canal waters (DAHMABUTRA et al., 1992; STAMPI $\boldsymbol{e t}$ al., 1993), poultry and pork (FESTY $\boldsymbol{e t}$ al.,1993; COLLINS et al., 1994; LAMMERDING $\boldsymbol{e t}$ al., 1994).

Although in very low porcentage, $\boldsymbol{A}$. butzleri has been found also in oviduct of sows and preputial fluid of male pigs (OLIVEIRA et al., 1997; 1999).The association of $\boldsymbol{A}$. butzleri with human

\footnotetext{
${ }^{1}$ Médico Veterinário, Doutor, Professor, Curso de Medicina Veterinaria, Universidade Luterana do Brasil (ULBRA). Hospital Veterinário. Rua Miguel Tostes, 101, Bairro São Luiz, Canoas, RS, 92420-280. E.mail: serjol@ zaz.com.br. Autor para correspondência.

${ }^{2}$ Médico Veterinario, MSc., Professor, Curso de Medicina Veterinária, Setor de Microbiologia Veterinaria, ULBRA.

${ }^{3}$ Médico Veterinário, MSc., Professor de Medicina de Aves, Faculdade de Medicina Veterinária, Universidade Federal do Rio Grande do Sul (UFRGS).

${ }^{4}$ Pesquisador Doutor, Laboratório de Diagnóstico Molecular, ULBRA.

${ }^{5}$ Pesquisador, Doutor, Simbios Biotecnologia.

${ }^{6}$ Professor, Doutor, Consultor de Microscopia Eletrônica, Laboratório de Microscopia Eletrônica, ULBRA
} 
enteritis, and its recovery in hogs and poultry suggests a potential human foodborne pathogen (WESLEY, 1996). In recent surveys, Arcobacter spp has been found more frequently from poultry than from red meats (DE BOER $\boldsymbol{e t}$ al., 1996; ATABAY \& CORRY, 1997; HARRAB et al., 1998), porcine fetuses, uterus and oviducts of sows and preputial fluid of boars and fattening pigs (OLIVEIRA $\boldsymbol{e t} \boldsymbol{a l}$., 1995; 1997; 1999).

The purposes of this study were to isolate Arcobacter spp from poultry carcass from abattoir in Brazil, and to utilize PCR analysis to establish the identity of the isolates.

\section{MATERIALS AND METHODS}

Carcasses. A total of 80 poultry carcasses (10 weekly) were taken from the line in the processing plant of an abattoir in the State of Rio Grande do Sul, Brazil. They were separately wrapped and transported from the factory to the laboratory under refrigerated conditions and examined within $2 \mathrm{~h}$ of slaughter.

Isolation Procedure. Samples were taken respectively from the skin and muscle of the neck of each carcass, for bacteriological examination. A piece of skin was cut and placed into liquid EMJH (Ellinghousen MacCulough Johnson and Harris Difco) medium in tubes. Portions of muscle of the neck were grinded in a mortar with liquid EMJH. Tubes were incubated for 5 days at $30^{\circ} \mathrm{C}$ under aerobic conditions, followed by plating by the STEEL \& MCDERMOTT (1984) membrane filter method onto sheep blood agar (brain heart infusion agar supplemented with $10 \%$ defibrinated sheep blood). One drop of the growth from EMJH was filtered onto blood agar through a $0.45 \mu$ pore size cellulose acetate filter (ATABAY \& CORRY, 1997). The plates were left lids-up on the bench for about $30 \mathrm{~min}$ to dry and then inverted and incubated under aerobic conditions at $30^{\circ} \mathrm{C}$ for 2 days.

Phenotypic testing. Suspect colonies on each plate were picked and checked by gram stain and inoculated into semi-solid EMJH (0.15\% agar). Growths from semi-solid EMJH were examined under dark-field microscopy (40x magnification) for motile gram negative curved rods. Cultures were purified by streaking on blood agar and checked for oxidase, catalase and growth on MacConkey Agar. Isolates were subcultured twice weekly into semisolid BHI medium, waiting for genotypic testing.

Electron micrograph. To visualize the cell wall a plasmolisis was promoted using $0.75 \%$ saline solution. The material was placed over support membrane and metalized with palladium- gold, and examined by the electronic microscope EM $208 \mathrm{~S}$ with 70kv, 40,000 X final magnification.

Isolation of DNA. Total DNA from each sample was isolated by phenol-chloroform procedure (SAMBROOK et al., 1989). Briefly, bacteria were harvested (15,000 X g; 2 min.), washed in phosphate bufered saline and suspended in distilled water. Sodium dodecyl sulfate (Sigma Chemical Co., St. Louis, MO) was added to a final concentration of $0.5 \%$. The samples were incubated for $10 \mathrm{~min}$ at $37^{\circ} \mathrm{C}$ with $1.0 \mathrm{mg}$ proteinase $\mathrm{K} / \mathrm{ml}$ (Sigma) and extracted with an equal volume of phenol and then chloroform:isoamyl alcohol (24:1). The DNA was precipitated using ethanol and resuspended in $50 \mu 1$ of distilled water.

Genotypic testing. Sequences for PCR primers were derived from the sequences of Arcobacter-specific and Arcobacter butzlerispecific 16S rRNA-based DNA probes (WESLEY $\boldsymbol{e} t$ al., 1995). Primers Arco I (5'- AGA GAT TAG CCT GTA TTG TAT C - 3') and Arco II (5' - TAG CAT CCC CGC TTC GAA TGA - 3') are targeted to $1223 \mathrm{bp}$ region of the Arcobacter 16S rRNA gene. Primers Arco II e Butz (5' - CTT GAC ATA GTA AGA ATG ATT TAG - 3') amplify a 463bp fragment of the 16S rRNA gene.

Amplification was performed in a $50 \mu \mathrm{l}$ volume containing 5.0ng of template DNA using Arco I and Arco II primers (HARMON \& WESLEY, 1996). PCR reaction products were visualized after separation by electrophoresis on $12.5 \%$ polyacrylamide gel and stained with a rapid silver nitrate staining method (SANGUINETTI et al., 1994).

\section{RESULTS AND DISCUSSION}

Forty eight Arcobacter spp strains were isolated from 37 poultry carcasses $(46.25 \%$ from a total of 80 examined), as shown in table 1 . PCR tests identified 41 strains as $\boldsymbol{A}$. butzleri and 07 as Arcobacter sp. Figure 1 presents the PCR products of some isolates. All Arcobacter isolates yielded a characteristic $1,223 \mathrm{bp}$ product. Only A. butzleri strains yielded both the 1,223 and 463bp amplicons.

All the isolates were oxidase positive and presented variable growth on MacConkey agar. Catalase test differentiated A. butzleri (negative or weak reaction) from other isolates typed as Arcobacter sp (strong positive reaction for catalase). Characteristic motile curved rods were seen by darkfield microscopy. Electron micrograph showed helycoidal bacteria with one polar flagella (Figure 2). 
Table 1 - Characterization of Arcobacter spp isolated from poultry carcasses.

\begin{tabular}{|c|c|c|}
\hline Samples & Muscle & Skin \\
\hline 2 & A. butzleri & - \\
\hline 6 & A. butzleri & - \\
\hline 7 & A. butzleri & - \\
\hline 8 & - & A. butzleri \\
\hline 11 & - & Arcobacter sp \\
\hline 12 & Arcobacter sp & A. butzleri \\
\hline 13 & Arcobacter sp & A. butzleri \\
\hline 15 & - & A. butzleri \\
\hline 16 & - & A. butzleri \\
\hline 18 & - & A. butzleri \\
\hline 21 & A. butzleri & - \\
\hline 24 & A. butzleri & A. butzleri \\
\hline 27 & A. butzleri & - \\
\hline 29 & - & Arcobacter sp \\
\hline 31 & A. butzleri & - \\
\hline 32 & A. butzleri & - \\
\hline 33 & A. butzleri & A. butzleri \\
\hline 34 & A. butzleri & A. butzleri \\
\hline 35 & Arcobacter sp & A. butzleri \\
\hline 36 & - & A. butzleri \\
\hline 37 & A. butzleri & A. butzleri \\
\hline 38 & - & A. butzleri \\
\hline 39 & A. butzleri & A. butzleri \\
\hline 40 & A. butzleri & A. butzleri \\
\hline 42 & - & A. butzleri \\
\hline 51 & - & A. butzleri \\
\hline 52 & A. butzleri & - \\
\hline 53 & - & A. butzleri \\
\hline 54 & A. butzleri & - \\
\hline 56 & A. butzleri & - \\
\hline 58 & A. butzleri & - \\
\hline 59 & A. butzleri & Arcobacter sp \\
\hline 62 & A. butzleri & - \\
\hline 65 & A. butzleri & A. butzleri \\
\hline 67 & A. butzleri & - \\
\hline 68 & Arcobactersp & - \\
\hline 69 & - & A. butzleri \\
\hline
\end{tabular}

Arcobacter spp have been reported more frequently from poultry than from red meats (WESLEY, 1996). Accordingly, poultry may be a significant reservoir of $\boldsymbol{A}$. butzleri. In France, $\boldsymbol{A}$. butzleri was recovered from $81 \%$ of poultry carcasses examined (LIOR \& WOODWARD, 1994). In Germany, HARRAB et al. (1998), isolated $52.3 \%$ (89 of 170) of freshly slaughtered broilers from 15 different flocks.

In the present report it is shown a similar high prevalence of Arcobacter in poultry, in which A. butzleri was recovered from $42.5 \%$ (34 of 80 ) and other Arcobacter $\boldsymbol{s p}$ from $8.7 \%$ (7 of 80 ) of the poultry carcasses. The characterization of samples as Arcobacter $\boldsymbol{s p}$ in the present report means that they could be $A$. cryaerophilus or A. skirrowii. Differentiation between these two species was not

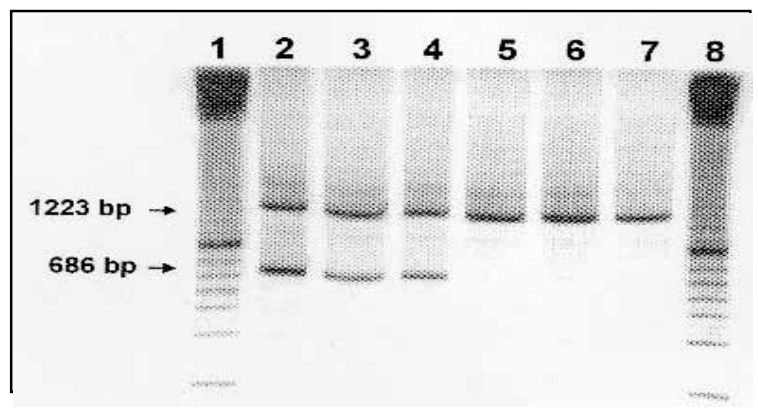

Figure 1 - Multiplex PCR on some Arcobacter samples isolated from poultry. Molecular weight marker lanes 1 and 8 . A. butzleri lanes 2, 3 and 4. Arcobacter sp lanes 5, 6 and 7.

done because it would require RFLP (restriction fragment length polymorphism). However, $\boldsymbol{A}$. butzleri were precisely identified by multiplex PCR.

The use of enrichment medium followed by plating after filtration (STEELE \& MC DERMOTT, 1984) was effective for isolation of Arcobacter from carcasses, as reported by LAMMERDING et al. (1994).

Tables 1 and 2 show the results of culturing skin and muscle samples from each carcass. It was not the objective of this research to establish a relation between porcentages of positive culture obtained from skin or muscle, nor relating the Arcobacter $\boldsymbol{s p}$ isolated. Nevertheless, it was shown that $52 \%$ of the strains were obtained from the muscle, while $48 \%$ from the skin. Data from table 2 also shows that $\boldsymbol{A}$. butzleri were isolated from seven carcasses from both skin and muscle. RFLP patterns would define if they were the same strain. Different Arcobacter species were isolated respectively from skin and muscle of four poultry carcasses, as shown in table 2 , meaning that there was infection or contamination by different microorganisms. A. butzleri were evenly distributed

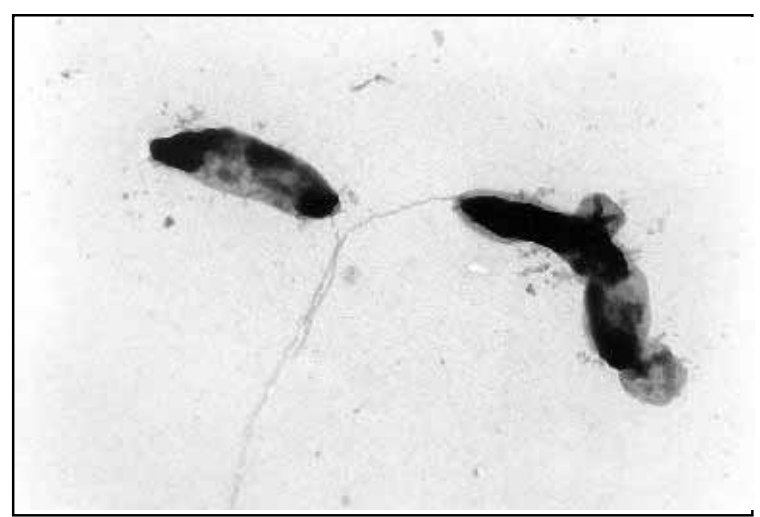

Figure 2 - Electron micrograph of two cells of Arcobacter spp showing their flagella. 
Table 2 - Isolation of Arcobacter spp from skin or muscle or both, from poultry carcasses.

\begin{tabular}{|c|c|c|c|c|c|}
\hline Samples & Muscle & Skin & Skin/muscle & Total & $\%$ \\
\hline Arcobacter butzleri & 13 & 10 & $7^{1}$ & 30 & 81.08 \\
\hline Arcobacter sp & 1 & 2 & 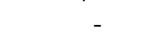 & 3 & 8.11 \\
\hline A. butzleri and & - & - & $4^{1}$ & 4 & 10.81 \\
\hline Arcobacter sp & & & & & \\
\hline Total & 14 & 12 & 11 & $37^{*}$ & 100 \\
\hline$\%$ & 37.84 & 32.43 & 29.73 & 100.00 & \\
\hline
\end{tabular}

(1) = Two positive culture from each carcass.

$(*)=37$ carcasses

in skin and/or muscle (21 from muscle and 20 from skin). There is no reference in the literature about reports on the distribution of the microorganisms in the skin and/or muscle from poultry carcasses.

\section{CONCLUSIONS}

Arcobacter spp, mainly $A$. butzleri were isolated from poultry carcasses in Brazil at a similar high prevalence as reported in some other countries. It is the first report on the occurrence of this microorganism in muscle and skin of poultry in South America.

\section{ACKNOWLEDGEMENTS}

We are indebted to José Gilvan Mancuso and Angelo Cesar Túlio for technical cooperation.

\section{REFERENCES}

ATABAY, H.I., CORRY, J.E.L. The prevalence of campylobacters and Arcobacters in broiler chickens. $\mathbf{J}$ Applied Microbiol, v.83, p.619 - 626, 1997.

BOER, DE, TILBURG, J.J.H.C., WOODWARD, D.L., et al. A selective medium for the isolation of Arcobacter from meats. Letters in Applied Microbiol, v.23, p.64-66, 1996.

COLLINS, C.I., WESLEY, I.V., MURANO, E.A. Incidence of Arcobacter spp in ground pork. Dairy Food Environ. Sanit, v.14, p.603, 1994.

DHAMABUTRA, N., KAMOL-RATHANAKUL, R., PIENTHEWEECHAI, K. Isolation of Campylobacter from the canals of Bangkok metropolitan area. J Med Assoc Thailand, v.75, p.350-363, 1992.

ELLIS, W.A., NEILL, S.D., O'BRIEN, J.J. et al. Isolation of Spirillum-like organisms from pig fetuses. Veterinary Record, v.102, p.106, 1978.

FESTY, B., SQUINAZI, F., MARIN, M., et al. Poultry meat and waters as the possible sources of A. butzleri associated human disease in Paris, France. Acta Gastro-Enterol Belg v.56, p.35, 1993 .
HARMON, K.M., WESLEY, I.V. Identification of Arcobacter isolates by PCR. Let Appl Microbiol, v.23, p.241-244, 1996.

HARRAB, B., SCHWARZ, S. WENZEL, S. Identification and characterization of Arcobacter isolates from broilers by biochemical tests, antimicrobial resistance patterns and plasmid analysis. Journal Veterinary Medicine, v.45, p.8794, 1998.

JACOB, J., LIOR, H., FUERPFEIL, I. Isolation of Arcobacter butzleri from a drinking water reservoir in eastern Germany. Z Hyg, v.193, p.557-562, 1993.

KIEHLBAUCH, J.A., BRENNER, D.J., NICHOLSON, M.A. et al Campylobacter butzleri sp. nov. isolated from humans and animals with diarrheal illness. Microbiology, v.29, p.376-385, 1991b.

LAMMERDING, A., HARRIS, J.E., LIOR, H. et al. An isolation method for Arcobacter butzleri from poultry. Dairy Food Environmental Sanitation, v.14, p.600, 1994.

LAUWERS, S, BREYNAERT, J, VAN ETTERIJK, $\boldsymbol{e}$ t al Arcobacter butzleri in the elderly in Belgium. In: NEWELL, D.G., KETLEY, J. Campylobacters, helicobacters and related organisms, Plenum, New York, 1996, p.515-517.

LERNER, J., BRUMBERGER, V., PREAC-MURSIC, V. Severe diarrhea associated with Arcobacter butzleri. European Journal Clinical Microbiol Infectious Diseases, v.13, p.660-662, 1994.

LIOR, H., WOODWARD, D. A serotyping scheme for Campylobacter butzleri. Microbiol Ecol in Health and Disease, v.4, S93, 1994.

NEILL, S.D., ELLIS, W.A., O'BRIEN, J.J. Designation of aerotolerant Campylobacter-like organisms from porcine and bovine abortions to the genus Campylobacter. Research Veterinary Science, v.276, p.180-186, 1979.

NEILL, S.D., CAMPBELL, J.N., O'BRIEN, J.J., et al. Taxonomic position of Campylobacter cryaerophila sp. nov. International Journal Systematic Bacteriology, v.35, p.342-356, 1985.

OLIVEIRA, S.J. DE, BOROWSKI, S.M., BARCELLOS, D.E. S N. Isolamento de Arcobacter (Campylobacter) cryaerophila de fetos suínos abortados. Ciência Rural, v.25, n.1, p.171$172,1995$.

OLIVEIRA, S.J. DE, BAETZ, A.L., WESLEY, I.V., et al. Classification of Arcobacter species isolated from aborted pig fetuses and sows with reproductive problems in Brazil. Veterinary Microbiology, v.57, p.347-354, 1997.

OLIVEIRA, S.J. DE, WESLEY, IV., BAETZ, A.L, et al. Arcobacter cryaerophilus and Arcobacter butzleri isolated from preputial fluid of boars and fattening pigs in Brazil. Journal Veterinary Diagnostic Investigation, v.11, p.462464, 1999.

PUGINA, P., BENZI, G., LAUWERS, S., et al. An outbreak of Arcobacter (Campylobacter) butzleri in Italy. Microb Ecol in Health and Disease, v.4, (Supplement), S94, 1991.

SAMBROOK, J., FRITSCH, E.F., MANIATIS, T Molecular cloning: A laboratory manual. 2.ed. Spring Harbor : Cold Spring Harbor Laboratory, 1989. 235p. 
SANGUINETTI, C.J., DIAS-NETO, E., SIMPSON, A.J.G. Rapid silver staining and recovery of PCR products separated on polyacrylamide gels. Biotechniques, v.17, p.915-919, 1994.

SCHROEDER-TUCKER, L., WESLEY, I.V., KIEHLBAUCH, J. A., et al. Phenotypic and ribosomal RNA characterization of Arcobacter species isolated from porcine aborted fetuses. Journal Vet Diagnostic Investigation, v.8, p.186-195, 1996.

STAMPI, S., VAROLI, O., ZANETTI, F., et al. Arcobacter cryaerophilus and thermophilic Campylobacters in a sewage treatment plant in Italy: two secondary treatments compared. Epidemiol Infection, v.110, p.633-639, 1993.

STEELE, T.W., MCDERMOTT, S.N. Technical note: the use of membrane filters applied directly to the surface of agar plates for the isolation of Campylobacter jejuni from feces. Pathology, v.16, p.263-265, 1984.
TAYLOR, D.N., KIEHLBAUCH, J.A., TEE, W., et al. Isolation of group 2 aerotolerant Campylobacter species from Thai children with diarrhea. Journal Infectious Disease, v.163, p.1062-1067, 1991.

VANDAMME, P., FALSEN, E., ROUSSAU, R., et al. Revision of Campylobacter, Helicobacter and Wolinella taxonomy: emendation of generic descriptions and proposal of Arcobacter gen. nov. International Journal Syst Bacteriology, v.41, n.1, p.88-103, 1991.

WESLEY, I. V., SCHROEDER-TUCKER, L., BAETZ, A.L., et al. Arcobacter specific and Arcobacter butzleri specific16 S rRNA-based DNA probes. Journal Clinical Microbiology, v.33, n.7, p.1691-1698, 1995.

WESLEY, I.V. Helicobacter and Arcobacter species: risks for foods and beverages. Journal of Food Protection, v.59, n.10, p.1127-1132,1996.

Ciência Rural, v. 31, n. 4, 2001. 